\title{
ADRENOCORTICAL FUNCTION IN HYPERCALCAEMIA OF INFANCY
}

\author{
BY \\ JOHN ANDERSON, E. G. BREWIS and W. TAYLOR \\ From the Departments of Medicine, Child Health and Physiology, King's College, Newcastle-upon-Tyne
}

(RECEIVED FOR PUBLICATION NOVEMBER 5, 1956)

Since it is possible that adrenocortical hormones may be implicated in the regulation of calcium metabolism (see Hollinger and Pattee, 1956, for references) we considered that it would be of interest to gain some knowledge of the adrenocortical function of patients with idiopathic hypercalcaemia of infancy.

We have investigated two such patients, one having a severe hypercalcaemic syndrome similar to that described by Schlesinger, Butler and Black (1956) and another with the benign type of hypercalcaemia. The only practicable method of assessing the adrenocortical function of these infants was to determine the urinary excretion of adrenocortical steroids before and after the administration of A.C.T.H. Since little is known about the status of the adrenal cortex in infancy we have also investigated the urinary excretion of adrenocortical steroids by six normal children and by one child who had recovered from hypercalcaemia to provide values for comparison.

The results obtained from this preliminary investigation indicate that adrenocortical function in hypercalcaemic infants is impaired, and that the concentration of calcium in the blood of such infants can be influenced by adrenocortical hormones. These findings seem to us of sufficient importance to justify publication at this stage in spite of the limited scope of the investigation.

\section{Methods}

Both patients (C.I. and A.W.) were fed throughout the period of study on a low-calcium diet which analysis showed contained $220 \mathrm{mg}$. calcium per day. Urinary collections were made on a metabolic bed of the usual type and only complete 24-hour collections were analysed. Plasma calcium was estimated by the method of Clark and Collip (1925), plasma inorganic phosphorus by that of Fiske and Subbarow (1925), blood urea by that of Archer and Robb (1925) and plasma cholesterol by that of Sackett (1925). Plasma sodium and potassium were determined using the EEL flame photometer. Urinary calcium was estimated by the method of Shohl and Pedley (1922). Urinary 'total 17-ketosteroids' were determined in 24-hour urine specimens by the method of Norymberski, Stubbs and West (1953) as modified by Gibson and Norymberski (1954). In the A.C.T.H. test 1 unit of A.C.T.H. was given intramuscularly every four hours for 10 days unless otherwise stated. The same batch of A.C.T.H. was used for the two tests on C.I. and the first test on A.W. Another batch was used for the second test on A.W. In patient C.I. cortisone was given orally in two equal doses.

\section{Results of Investigation of 'Total 17-Ketosteroid' in Urine of Six Normal Male Children}

Four of the children were in hospital recovering from infection; their ages ranged from 3 to 18 months. Two children, aged 2 years, with no significant medical history were leading a normal life at home. No A.C.T.H. was administered to any of these children.

The mean excretion of urinary 'total 17-ketosteroids' in this group was $4.0 \mathrm{mg}$. per 24 hours, with a range of $3 \cdot 5$ to $5 \cdot 2 \mathrm{mg}$. (11 determinations). It is this mean value which has been shown in Figs. 1,2 and 3.

'Total 17-Ketosteroids' in Child Recovered from Hypercalcaemia. The male child who had recovered from hypercalcaemia was a full-term normal delivery. At the age of 6 months he was treated for meningococcal septicaemia but after discharge he became ill again and had a severe urinary infection; repeated subdural taps were negative. He did not thrive and had recurrent bouts of pyrexia which were only temporarily improved when treated with antibiotics. When he was 1 year old the plasma calcium concentration was found to be $16.0 \mathrm{mg}$. per $100 \mathrm{ml}$. and the blood urea level $101 \mathrm{mg}$. per $100 \mathrm{ml}$. A month later the plasma calcium had risen to $17 \cdot 6 \mathrm{mg}$. per $100 \mathrm{ml}$. He was fed on a low-calcium diet and began to improve slowly; the plasma calcium fell to $12.7 \mathrm{mg}$. per $100 \mathrm{ml}$. and blood urea to $96 \mathrm{mg}$. 
per $100 \mathrm{ml}$. On October 26, 1954, when he was aged 2 years, the plasma calcium and blood urea were 10.8 and $51 \mathrm{mg}$. per $100 \mathrm{ml}$. respectively. A 24-hour urine specimen was collected on September 10,1956 , when, at the age of 3 years 10 months, he was fit and well. His urinary excretion of 'total 17-ketosteroids' was $6.3 \mathrm{mg}$. per 24 hours, which is above the range of the six normal children, but as he was over a year older and had had hypercalcaemia he was not included in the normal series.

\section{Patients' Reports}

Case C.I. C.I., a boy, was born on May 17, 1955, a fullterm normal delivery, birth weight $6 \mathrm{lb}$. Both parents and a sister were healthy. He was never breast fed but had Nestlé's (sweetened condensed) milk and 'ostermilk' (a full-cream milk) for three weeks. Because he vomited several times daily and was gaining weight only slowly he was changed to National dried milk. At the age of 4 months (September 27) he was admitted to hospital as he was only taking about $13 \mathrm{oz}$. of milk per day and was losing weight.

On admission he was a small infant weighing $9 \frac{1}{2} \mathrm{lb}$. He was not dehydrated. He had the characteristic facies seen in the severe type of hypercalcaemia of infancy. The skin of the trunk, limbs and face was light brown and the sclerae of the eyes blue, but no buccal pigmentation was seen. There was a loud precordial systolic murmur; his blood pressure was $160 / 100 \mathrm{~mm}$. $\mathrm{Hg}$. The urine was acid and contained a trace of albumin as well as casts and red and white blood cells; on culture Escherichia coli and Proteus were isolated. The blood white cell count was 11,450 per c.mm., and the Mantoux reaction was negative. Radiography revealed a marked increase of calcification of all bones, but there was no nephrocalcinosis. The concentrations of plasma calcium, sodium, potassium and of blood urea before and during the present investigation are shown in Table 1, together with plasma inorganic phosphorus and cholesterol concentrations which were also determined later in the investigation.

Treatment And Course. The infant was fed with a low-calcium milk with no added vitamin $D$. During the first months in hospital several phases of irregular pyrexia occurred. These were treated with sulphadimidine and streptomycin without improvement. His weight did not change significantly, and the hypercalcaemia persisted. In April, 1956, the plasma calcium concentration had fallen to $12.8 \mathrm{mg}$. per $100 \mathrm{ml}$. (see Table 1), but his condition was deteriorating clinically and it was then decided to begin investigation of adrenocortical function.

A.C.T.H. Test. During April and May two A.C.T.H. tests were carried out. The results of the tests, which consisted of the injection of 1 unit of A.C.T.H. every four hours for 10 days, are shown in Fig. 1. On neither occasion was there any significant increase in excretion of urinary 'total 17-ketosteroids', so that presumably there was no response to the A.C.T.H. (the slight apparent increase in 'total 17-ketosteroids' during the first test is probably not significant). There was no change in plasma calcium concentration during this period, as far as

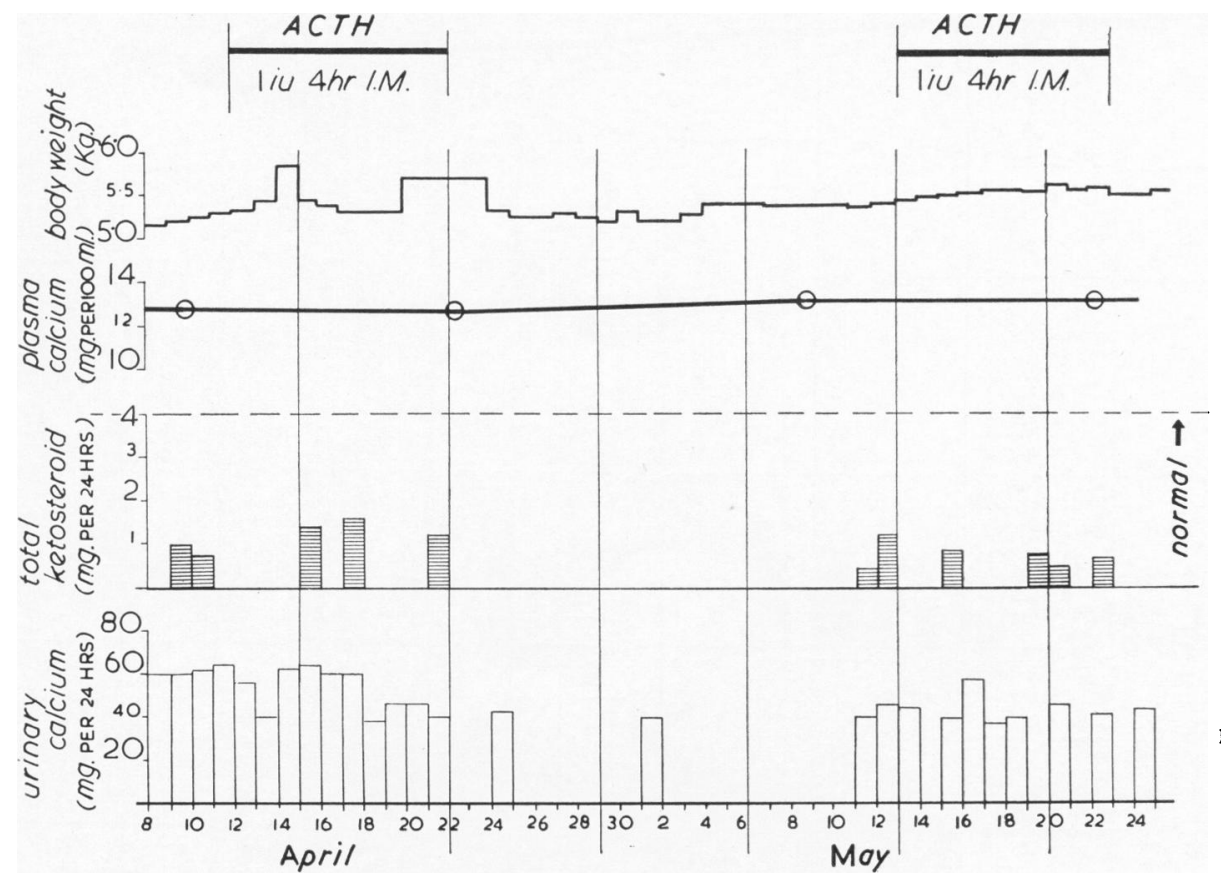

Fig. 1.-Response of patient C.I. to A.C.T.H. 
TABLE 1

CONCENTRATIONS OF PLASMA CALCIUM, SODIUM, AND POTASSIUM AND BLOOD UREA IN CASE C.I.

\begin{tabular}{|c|c|c|c|c|c|c|c|}
\hline Date & $\begin{array}{c}\text { Plasma } \\
\text { Calcium } \\
(\mathrm{mg} . / 100 \mathrm{ml} .)\end{array}$ & $\begin{array}{c}\text { Plasma } \\
\text { Inorganic } \\
\text { Phosphorus } \\
(\mathrm{mg} . / 100 \mathrm{ml} .)\end{array}$ & $\begin{array}{c}\text { Plasma } \\
\text { Sodium } \\
\text { (mEq./1.) }\end{array}$ & $\begin{array}{c}\text { Plasma } \\
\text { Potassium } \\
(\mathrm{mEq} . / 1 .)\end{array}$ & $\begin{array}{c}\text { Plasma } \\
\text { Cholesterol } \\
(\mathrm{mg} . / 100 \mathrm{ml} .)\end{array}$ & $\begin{array}{c}\text { Blood } \\
\text { Urea } \\
\text { (mg./100 ml.) }\end{array}$ & Remarks \\
\hline $\begin{array}{r}20.10 .55 \\
2.2 .56\end{array}$ & $\begin{array}{l}14 \cdot 7 \\
16 \cdot 0\end{array}$ & $=$ & 154 & $5 \cdot 0$ & $=$ & $\begin{array}{l}146 \\
140\end{array}$ & \multirow{7}{*}{$\begin{array}{l}\text { On low calcium diet } \\
\text { A.C.T.H begun } \\
\text { A.C.T.H. ended } \\
\text { Day after cessation of A.C.T.H. } \\
\text { A.C.T.H. begun } \\
\text { A.C.T.H. ended. Sodium chloride } \\
\text { and potassium chloride begun } \\
6 \mathrm{mg} \text {. cortisone o.d. } \\
8 \mathrm{mg} \text {. cortisone o.d. } \\
12 \mathrm{mg} \text {. cortisone o.d. } \\
16 \mathrm{mg} \text {. cortisone o.d. } \\
24 \mathrm{mg} \text {. cortisone o.d. } \\
28 \mathrm{mg} \text {. cortisone o.d. } \\
28 \mathrm{mg} \text {. cortisone o.d. } \\
28 \mathrm{mg} \text {. cortisone o.d. }\end{array}$} \\
\hline 9.4 .56 & $12 \cdot 8$ & $5 \cdot 7$ & 152 & $3 \cdot 2$ & - & 76 & \\
\hline $\begin{array}{l}12.4 .56 \\
21.4 .56\end{array}$ & 二 & 二 & 二 & 二 & - & 二 & \\
\hline $\begin{array}{r}22.4 .56 \\
9.5 .56\end{array}$ & $\begin{array}{l}12 \cdot 5 \\
13 \cdot 2\end{array}$ & $\begin{array}{l}5.4 \\
5.6\end{array}$ & $\begin{array}{l}148 \\
138\end{array}$ & $\begin{array}{l}4.2 \\
3.6\end{array}$ & $\bar{z}$ & $\begin{array}{l}70 \\
72\end{array}$ & \\
\hline $\begin{array}{l}13.5 .56 \\
22.5 .56\end{array}$ & $\overline{13 \cdot 2}$ & $\overline{5.6}$ & $\overline{130}$ & $\overline{3.8}$ & 二 & $\overline{76}$ & \\
\hline & & & & & & & \\
\hline $\begin{array}{r}1.6 .56 \\
5.6 .56 \\
13.6 .56 \\
16.6 .56 \\
2.7 .56 \\
25.7 .56 \\
30.7 .56 \\
20.8 .56\end{array}$ & $\begin{array}{r}12 \cdot 7 \\
13 \cdot 2 \\
13 \cdot 0 \\
11 \cdot 9 \\
11 \cdot 3 \\
9 \cdot 8 \\
10 \cdot 0 \\
10 \cdot 0\end{array}$ & $\begin{array}{l}5 \cdot 5 \\
5 \cdot 4 \\
5 \cdot 3 \\
5 \cdot 2 \\
5 \cdot 2 \\
4 \cdot 1 \\
4 \cdot 1 \\
4 \cdot 1\end{array}$ & $\begin{array}{l}152 \\
147 \\
140 \\
156 \\
149 \\
152 \\
150 \\
152\end{array}$ & $\begin{array}{l}3 \cdot 8 \\
3 \cdot .9 \\
3 \cdot 1 \\
3 \cdot 9 \\
4 \cdot 1 \\
4 \cdot 3 \\
4 \cdot 2 \\
4 \cdot 0\end{array}$ & $\begin{array}{l}\overline{199} \\
200 \\
206 \\
\overline{206} \\
\overline{232}\end{array}$ & $\begin{array}{l}66 \\
70 \\
65 \\
60 \\
62 \\
56 \\
54 \\
52\end{array}$ & \\
\hline
\end{tabular}

could be assessed by the limited number of blood samples available for analysis, but the urinary calcium concentration fell slightly during the first test. There were repeated sudden increases in weight which were not maintained, particularly during, and immediately after, the first test. Two weeks after the first A.C.T.H. test the infant developed a left-sided, lower motor neurone type facial paralysis which persisted for a month and then disappeared. Its occurrence was never satisfactorily explained.
After the second A.C.T.H. test the plasma sodium level was observed to have fallen to $130 \mathrm{mEq} . / 1$. and the plasma potassium level was $3.8 \mathrm{mEq} . / 1$. He was given $0.5 \mathrm{~g}$. sodium chloride twice daily and $0.5 \mathrm{~g}$. potassium chloride once daily; this treatment has been continued since then. Repeated determination of plasma sodium and potassium have shown concentrations within the normal range (Table 1).

Cortisone Administration. In view of the lack of

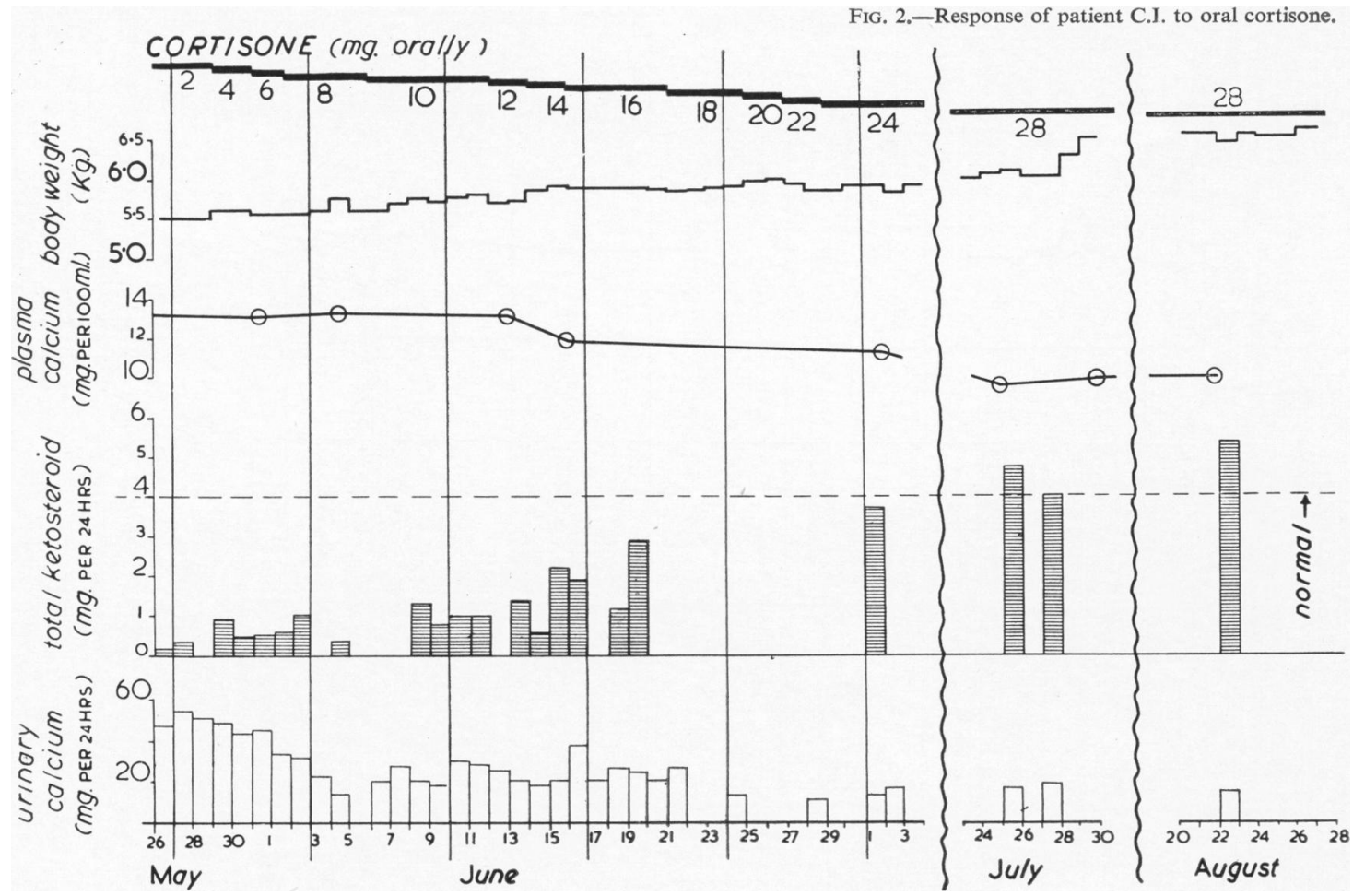


response to A.C.T.H. it was decided to treat the infant with oral cortisone. To ascertain a dose which might reduce the plasma calcium concentration to normal and to prevent as far as possible any risk of overdosage the amount of cortisone administered was gradually increased from a starting level of $2 \mathrm{mg}$. per day. The output of urinary 'total 17-ketosteroids' while the infant was on this regimen is shown in Fig. 2. Blood analyses carried out during this period are given in Table 1 . It can be seen that, as the dose of cortisone was gradually increased, (i) plasma concentrations of sodium, potassium and cholesterol did not change appreciably (Table I). (ii) The blood urea concentration gradually decreased (Table 1). (iii) Plasma concentrations of calcium, inorganic phosphorus and urinary calcium were markedly reduced, and there was a gradual increase in the weight of the infant. When the dose of cortisone had reached $28 \mathrm{mg}$. per day plasma calcium concentration became normal (Fig. 2 and Table 1). (iv) The excretion of urinary 'total 17-ketosteroids' gradually increased up to the level found in normal infants (Fig. 2).

During the administration of cortisone the pigmentation of the skin decreased considerably, but is still present. In spite of the disappearance of the hypercalcaemia the infant's development is grossly retarded. At 15 months he cannot sit up of his own accord, he makes only primitive noises, and is emotionally stunted. The fontanelle admits only the tip of the finger, and the sutures of the skull are rapidly fusing.

Case A.W. A.W., a girl, was born on May 22, 1956, a full-term normal delivery, birth weight $6 \mathrm{lb} .12 \mathrm{oz}$. Both parents and a sister were healthy. She was never breast fed, but developed well on National dried milk with the addition of one teaspoonful of cod-liver oil daily. At the age of 6 months she began to refuse feeds and to lose weight. Two months later she developed a cough and would sometimes vomit afterwards. Mixed feeding was tried but not tolerated and though bland feeds were taken without difficulty, she did not thrive.

On admission in March, 1956, at the age of 8 months, she weighed only $13 \mathrm{lb}$. $3 \mathrm{oz}$. and her muscles were hypotonic. The skin showed a diffuse, bright lemon- yellow coloration. The liver was palpable. The cardiovascular system, including blood pressure, was normal. The urine was acid, and though on occasions traces of albumin were found there was no significant number of white cells. Serum proteins were normal; radiography of the skeleton revealed no abnormality; the Mantoux reaction was negative. The concentrations of plasma calcium, inorganic phosphorus, sodium, potassium and cholesterol, and of blood urea before and during the present investigation are shown in Table 2 .

Treatment and Course. During the first six weeks in hospital she had several attacks of pyrexia which subsided without chemotherapy. She was fed on a low-calcium diet and although feeding was satisfactory her weight did not increase nor was there any decrease in plasma calcium concentration. The yellow coloration of the skin decreased during this period but increased again during the first A.C.T.H. test.

A.C.T.H. Tests. The results of the two tests are shown in Fig. 3 and Table 2. It can be seen that, in the first test, (i) there was a marked fall in plasma calcium concentration and a definite increase in the urinary 'total 17-ketosteroids' to almost normal levels (Fig. 3). (ii) Administration of 24 units of A.C.T.H. per day did not appear to increase the response as judged by urinary 'total 17-ketosteroids' or plasma calcium concentrations, but there was a marked decrease in urinary calcium excretion associated with this larger dose (Fig. 3). (iii) The plasma inorganic phosphorus concentrations decreased (Table 2). (iv) There was a dramatic reduction in the concentration of plasma cholesterol (Table 2).

Associated with these changes was a great change in plasma sodium and potassium concentrations (Table 2). The infant appeared very well at this time but she has been given $0.5 \mathrm{~g}$. sodium chloride since then, and her plasma sodium and potassium have remained at normal values. There was also a marked increase in blood urea during the test.

The failure of the second A.C.T.H. test to evoke a similar response may have been due to the fact that another batch of the hormone was used in this test.

TABLE 2

CONCENTRATIONS OF PLASMA CALCIUM, INORGANIC PHOSPHORUS, SODIUM, POTASSIUM AND CHOLESTEROL AND BLOOD UREA IN CASE A.W.

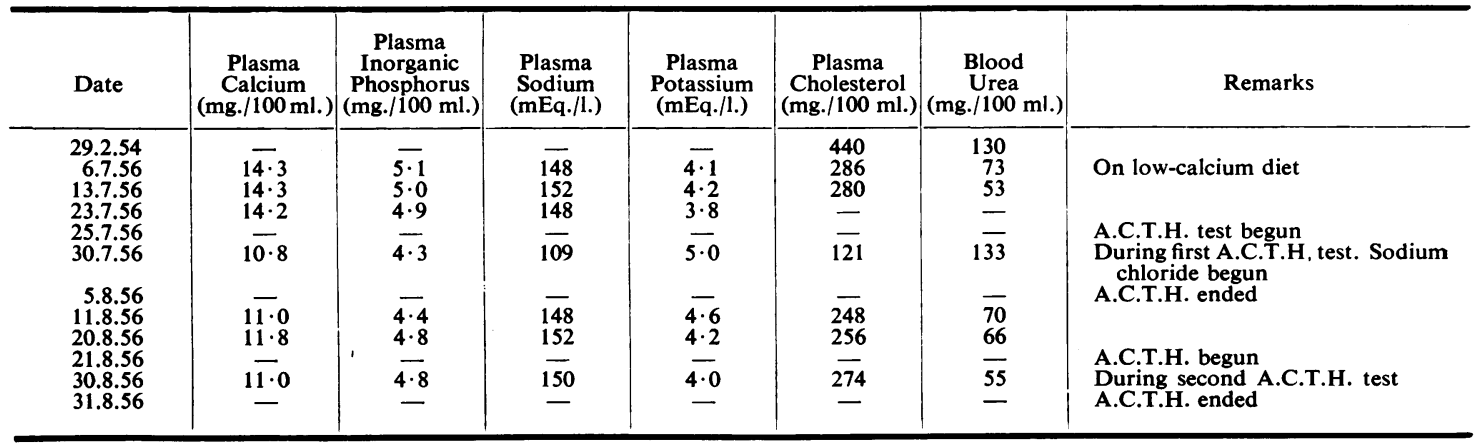


Fig. 3.-Response of patient A.W. to A.C.T.H

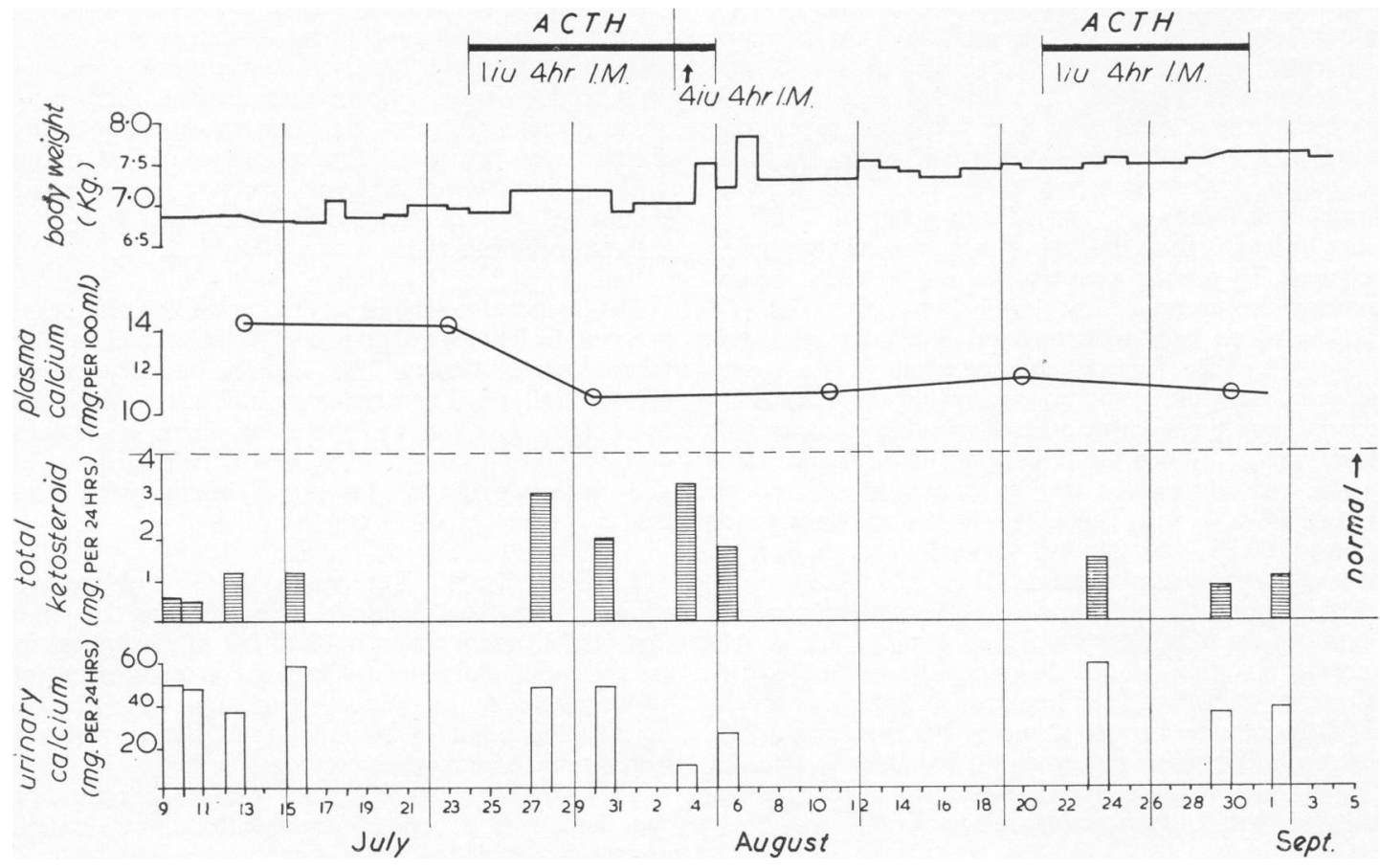

Since these tests the baby's condition has continuously improved. She is beginning to grow and gain in weight. She would always have been classed as a clinically moderate case, and it is felt that she will eventually become normal.

\section{Discussion}

The tests on patient C.I., who had the severe type of hypercalcaemia, showed that there was little or no adrenocortical response to A.C.T.H. Urinary 'total 17-ketosteroid' excretion remained low and there was no significant change in the concentrations of plasma calcium and inorganic phosphorus and blood urea; there was, however, a slight decrease in urinary calcium. These results suggest that the infant had a very much impaired adrenocortical function but it is also possible that the amount of A.C.T.H. administered was insufficient to stimulate the adrenal cortex. This possibility seems unlikely, however, in view of the dramatic response of patient A.W. to the same dose.

The response of patient C.I. to cortisone was very marked in contrast to his response to A.C.T.H. Plasma calcium and inorganic phosphorus and urinary calcium concentrations were gradually reduced, until at a dose of $28 \mathrm{mg}$. per day the plasma calcium concentration was normal. At the same time the urinary excretion of 'total 17-ketosteroids' gradually increased to just above the normal range (Fig. 2).

In contrast, the patient (A.W.) with the benign type of hypercalcaemia responded well to the first A.C.T.H. test as evidenced by the significant rise in 'total 17-ketosteroid' excretion, and by the dramatic fall in plasma calcium concentration. It will be noted that the plasma calcium concentration began to increase only very slowly when the A.C.T.H. was withdrawn. This response to A.C.T.H. suggests that in this infant the impaired adrenal function was secondary to failure of the pituitary to produce A.C.T.H. The impairment of adrenal function, whatever the cause, appears to be temporary, for most of the patients of her type make a complete recovery. Therefore it was not considered desirable to treat this patient with cortisone.

Creery and Neill (1954) and Forfar, Balf, Maxwell and Tompsett (1956) have found a high incidence of hypercholesterolaemia in hypercalcaemia of infancy. No mention was made by these authors of the effect of cortisone on plasma cholesterol concentration. Unfortunately determinations of the plasma cholesterol of patient C.I. were not made until treatment was begun, but in patient A.W. there was a striking fall in plasma cholesterol during the first A.C.T.H. test. Conn, Vogel, Louis and Fajans (1950) have 
reported the same effect of A.C.T.H. on plasma cholesterol of adults.

While there are many possible explanations of the results obtained in these investigations we feel that at this stage speculation would be unwise. It does seem, however, that impaired adrenal function may be an important factor in hypercalcaemia of infancy. Furthermore, the evidence presented suggests that the infant with severe hypercalcaemia may have primary adrenal dysfunction while the case of the benign type may have secondary adrenal dysfunction. It is possible that there may be morphological changes in the adrenals or pituitaries of these patients but a survey of the recorded cases that have come to necropsy does not support this view.

\section{Summary}

Two infants, one with severe hypercalcaemia of infancy and the other with the benign type, had their adrenocortical function assessed by an A.C.T.H. test.

The infant with the benign type responded to the A.C.T.H. test as judged by the urinary 'total 17-ketosteroids' excretion and the restoration of plasma calcium concentrations. The severely hyper- calcaemic infant did not respond to A.C.T.H. but his plasma calcium concentration became normal on treatment with $28 \mathrm{mg}$. cortisone per day.

It is suggested that impaired adrenal function may be an important factor in hypercalcaemia of infancy.

One of us, J.A., wishes to thank the Dean of Medicine for a personal grant. The success of the experiments was mainly due to the unceasing efforts of Sister $\mathbf{J}$. Clayton and the nurses of Ward 7, Walkergate Hospital. Dr. M. Wallace gave valuable clinical assistance. Professor C. E. Dent kindly loaned us the rubber urine collectors. Mr. R. Richardson was responsible for providing the metabolic bed. Dr. R. D. Eastham and Miss C. A. Buchan gave valuable technical assistance.

\section{REFERENCES}

Archer, H. E. and Robb, G. D. (1925). Quart. J. Med., 18, 274.

Clark, E. P. and Collip, J. B. (1925). J. biol. Chem., 63, 461.

Conn, J. W., Vogel, W. C., Louis, L. H. and Fajans, S. S. (1950) J. Lab. clin. Med., 35, 504

Creery, R. D. G. and Neill, D. W. (1954). Lancet, 2, 110

Fiske, C. H. and Subbarow, Y. (1925). J. biol. Chem., 66, 375.

Forfar, J. O., Balf, C. L., Maxwell, G. M. and Tompsett, S. L. (1956). Lancet, 1,981.

Gibson, G. and Norymberski, J. K. (1954). Ann. rheum. Dis., $13,59$.

Hollinger, H. Z. and Pattee, C. J. (1956). Canad. med. Ass. J., 74, 912 .

Norymberski, J. K., Stubbs, R. D. and West, H. F. (1953). Lancet,

Sackett, G. E. (1925). J. biol. Chem., 64, 203.

Schlesinger, B. E., Butler, N. R. and Black, J. A. (1956). Brit. med. J., 1, 127.

Shohl, A. T. and Pedley, F. G. (1922). J. biol. Chem., 50, 537. 